\section{Alder Hey}

\section{Lawrence}

\section{The taken for granted and professional practice}

A nyone looking for an explanation of the scandal at Alder Hey in general rather than specific or psychological terms could do worse than turn to history. Not just to the last few years that is, but to half a millennium of Western medical tradition. Pathologists and others will doubtless draw relevant conclusions from the episode and perhaps more guidelines will be added to those already in place. For the historian one lesson seems strikingly clear. The episode is a vivid demonstration of how what are eventually seen as ordinary and acceptable practices are gradually built over a long period of time during which their moral dimensions become completely hidden. It takes a magnified example of the ordinary for the substructure of the taken for granted to be revealed.

There are hints that the practice of human anatomy occurred very occasionally in antiquity and we can be certain that it infrequently did in the Middle Ages. There is no record, however, of the retention of parts for educational or other purposes. It was in the Renaissance that anatomy was crowned the queen of the medical sciences and it was from then that the anatomists began to retain skeletons and organs for their private collections and those of the institutions that they served. In Britain, corpses available for dissection were those of judicially hanged felons. Dissection was regarded as the last punishment that could be inflicted on a criminal. Hanged criminals largely came from the poorer classes and, as Ruth Richardson has shown, popular attitudes to, and rituals surrounding, the dead body comprised a strange mixture of Christianity and ancient folk beliefs. ${ }^{1}$ In any event this combination served to produce reverence for the intact corpse and a hatred of anatomists. Mobs showed their moral disapproval by snatching corpses from the gallows. Surgeons would scarcely have asked permission for retention of parts. But most anatomical collections were not built from this resource. Resurrected bodies and the cadavers of unclaimed poor dying in hospital sold illicitly were the largest source. Bodies out of sight and out of mind were the basis of the huge collections that were amassed in the 18th century.

The case of pathology is slightly different. Like dissection, postmortem examinations began in the Renaissance. By the 18th century the practice had grown in scale. They were usually done on the poor, the only inmates of hospitals in this period. Permission for postmortem examination would routinely be asked for-hospital managers of the time were careful of the reputation of their institutions. But no doubt physicians removed and retained morbid specimens without asking permission, the best guess being that they saw no need to make such a request of the poor and that, even had they thought to do so, they could be sure of refusal. Who would stop a learned physician leaving a hospital carrying a portmanteau lest it contained a cancerous liver? The great collections of the late 19th century were often both anatomical and pathological. It is hard to credit that the original owners of the myriad parts that John Hunter acquired and that were subsequently displayed at Lincoln's Inn Fields could have imagined their innards would be on show for professional and public consumption. This of course raises a side question that is not the historian's territory. If people wish to be buried entire after granting permission for postmortem examination do they want to be interred abnormal growths and all? History provides no precedents.

By the 19th century pathology had displaced anatomy as the queen of the medical sciences. It was then that the large collections of the hospital medical schools were built up. By this time the practice of removing and retaining organs was commonplace. No one thought twice about it. If it ever had a visible moral dimension it had disappeared. A Victorian pathologist would have been shocked at the suggestion he might have been doing something improper or at worst immoral in carrying out such acts. Medicine was not unique in its attitude to the bodies of others. Cultural anthropologists thought nothing of bringing back shrunken heads and physical anthropologists acquired bones by the sackful. Egyptologists plundered tombs for mummies and funerary urns for organs. The bodies of those who could not protest were fair game in the advancement of knowledge.

Anatomists started to have a better time of it in the 19th century. Bodysnatching had reached scandalous pro- portions by the 1820s when Burke and Hare increased their supply of bodies to Robert Knox in Edinburgh by bumping off the unwashed and unwanted: a practice known as Burking. But reform was driven by more than scandal. Radicals and freethinkers who had no time for religion or folk belief saw in science the only possible means of social progress. Embodying this ideology was the creator of Utilitarianism, Jeremy Bentham, and father to the Anatomy Act of 1832. Bentham himself asked for and was granted a postmortem examination. His remains grace the institution whose foundation he inspired: University College London.

The Anatomy Act made provision for the unclaimed bodies of paupers to be handed over for anatomical purposes. The Act is a salutary reminder that what looks like progress now was not deemed such nearly 200 years ago. Critics of the Act claimed that the stigma of dissection once attached to the criminal was now affixed to the pauper.

We have no history of the growth of willingness among the general public to donate their bodies for medical purposes. The rise of rationalism and humanism as secular creeds in the late 19th century must have played a part. Orthodox medicine by the early 20th century was reaching far more of the population than ever before. Its esteem was growing although with few exceptions, surgery being one, it is hard to know why. It is possible it took, for example, insulin, penicillin, cortisone and a general improvement in the population's health (having nothing to do with medicine but regarded as linked to it) that led to large scale body donation after the second world war. If the medical profession ever had a Golden Age it disappeared 20 years ago.

Old beliefs and assumptions run deep. The "what do I care what happens to me when I'm dead" does not prevail everywhere. The rituals of the funeral and burial, viewing the corpse for example, are profoundly important to many. Professional practices, such as retaining body parts are often created in one moral climate and become unquestioned in another. Human experimentation that doctors did not even consider they were doing until the 1970s is another example. But for some, these practices do have moral relations and it often takes an event in Cinemascope to display them. Too close for comfort now, but at a distance it would be interesting to have a proper study of the beliefs, assumptions and religious practices of those grieving at Alder Hey.

More is at work here than the history of something peculiar to medicine. We live in a professional society. ${ }^{2}$ We rely on and believe in professional expertise to make our society tick. Professionals, 
however, are not automata. Their professional status has been historically achieved not simply through technical know-how but by the claim to being important bearers of standards and values. Yet those standards and values often lie alongside professional practices that seem just that, professional practices, and do not call for inquisition. Take a nice example. By every account Sir William Osler was not only a great diagnostician but a truly caring and devoted doctor, a loving parent and husband, a friend to the needy, a bibliophile and cultured man. None the less he was also a dedicated pathologist. On one occasion, confronted with a family who refused permission for postmortem examination he returned to the mortuary at night to remove the suprarenal gland through the patient's anus. Concern for sensibilities that obstructed medical progress was not in his field of vision.

We may live in a professional society. But professionals are ceasing to be the significant moral leaders that they created themselves as in Victorian society. Ordinary professional practices are increasingly under scrutiny from within and without. But it is often hard to see from inside the goldfish bowl. It took the Maoris to tell the anthropologists that taking ancestral bones from their resting place could be a sacrilegious act. It took outsiders to say that the moral codes of non-professionals may merit respect.

J Epidemiol Community Health 2002;0:5-6

\section{Author's affiliation}

C Lawrence, The Wellcome Trust Centre for the History of Medicine, University College London, 24 Eversholt Street, London NWI IAD, UK

\section{REFERENCES}

1 Richardson R. Death, dissection and the destitute. London: Routledge and Kegan Paul, 1987

2 Perkin $\mathbf{H}$. The rise of professional Society. England since 1880. London: Routledge, 1989.

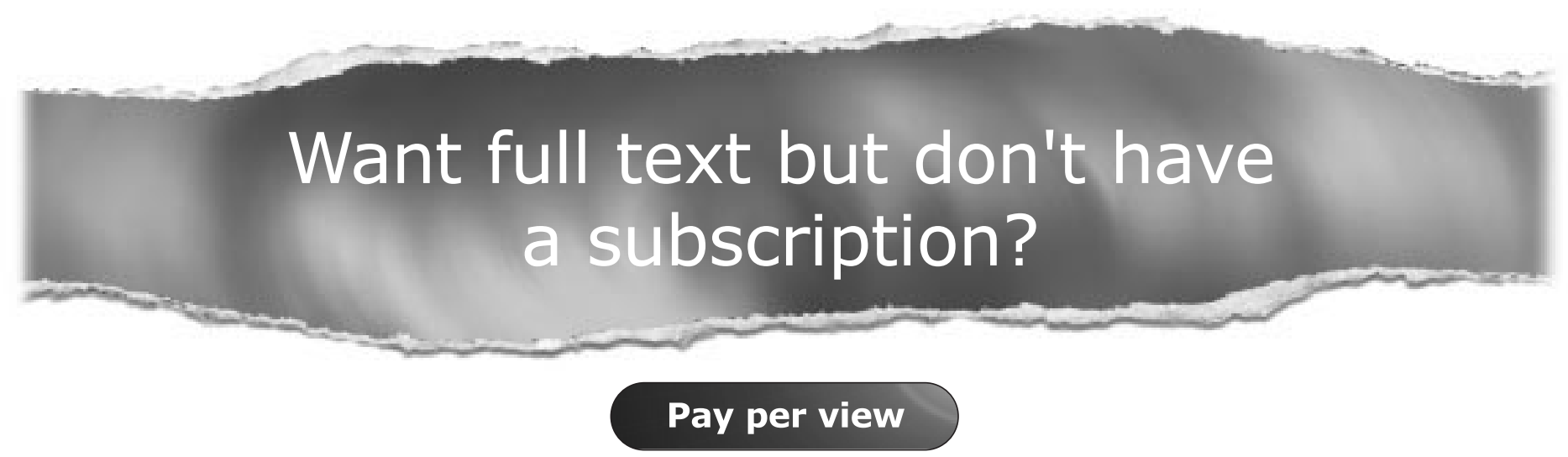

For just \$8 you can purchase the full text of individual articles using our secure online ordering service. You will have access to the full text of the relevant article for 48 hours during which time you may download and print the pdf file for personal use.

\section{www.jech.com}

